\title{
Evaluation of the Relationships between Obesity and Central Retinal Thickness, Retinal Nerve Fiber Layer, Intraocular Pressure, and Central Corneal Thickness in Children
}

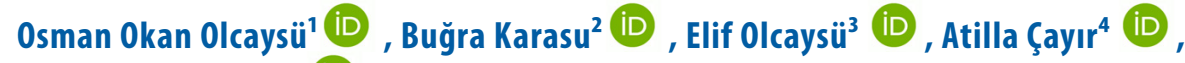 \\ Ali Rıza Cenk Çelebi ${ }^{5}$ iD
}

${ }^{1}$ Göz Hastalıkları Kliniği, İstanbul Sait Çiftçi Devlet Hastanesi, İstanbul, Türkiye

${ }^{2}$ Göz Hastalıkları Kliniği, İstanbul Tuzla Hastanesi, İstanbul,Türkiye

${ }^{3}$ Sağlık Bilimleri Üniversitesi Bakırköy Dr. Sadi Konuk Eğitim ve Araştırma Hastanesi, Çocuk Sağlığı ve Hastalıkları, İstanbul, Türkiye

${ }^{4}$ Erzurum Şehir Hastanesi, Çocuk Endokrinolojisi, Erzurum, Türkiye

${ }^{5}$ Acıbadem Mehmet Ali Aydınlar Üniversitesi, Atakent Eğitim ve Araştırma Hastanesi Göz Kliniği, İstanbul, Türkiye

Osman Okan OLCAYSÜ

Buğra KARASU

Elif OLCAYSÜ

Atilla ÇAYIR

Ali Rıza Cenk ÇELEBi

\section{Correspondence: Buğra Karasu}

İstanbul Tuzla Devlet Hastanesi, Göz Hastalıkları Kliniği, İstanbul, Türkiye

Phone: +905493825082

E-mail: bugra_karasu@hotmail.com

\begin{abstract}
Purpose: The purpose of this study was to investigate the effect of childhood obesity on the retinal nerve fiber layer (RNFL), retinal thickness, central corneal thickness and intraocular pressure.

Method: Children with obesity (n:24) (Group 1; n:48 eyes) and healthy children (n:23) (Group 2; n:46 eyes) were included in the study. Average RNFL thickness, central $1 \mathrm{~mm}$ diameter of foveal thickness (CFT) and subfoveal choroidal thickness (SFCT) were measured using the fourier domain - optical coherence tomography (FD-OCT). Central corneal thickness (CCT) was measured using contact ultrasonic pachymetry and intraocular pressure (IOP) using Goldmann applanation tonometry.

Results: The mean IOP in Group 1 was found to be significantly higher $(\mathrm{p}=0.002)$ and $16.1 \pm 3.1 \mathrm{mmHg}$ in group 1 and $13.6 \pm 3.2$ $\mathrm{mmHg}$ in group 2, respectively. Mean RNFL, CFT and SFCT significantly were lower in group $1(p<0.05)$ than group 2 . The average RNFL was detected to $107.9 \pm 10.5 \mu \mathrm{m}$ in group 1 and $112.6 \pm 11.8 \mu \mathrm{m}$ in group 2 , respectively $(\mathrm{p}=0.001)$. Mean CFT was found to be $231.6 \pm 14.4 \mu \mathrm{m}$ in group 1 and $245.9 \pm 19.98 \mu \mathrm{m}$ in group 2, respectively $(\mathrm{p}=0.001)$. The average $S F C T$ was observed to $193.3 \pm 15.3 \mu \mathrm{m}$ in group 1 and $221 \pm 25.1 \mu \mathrm{m}$ in group 2, respectively $(p<0.001)$. Although CCT was relatively higher in group 1 , no statistically significant difference was observed among the groups $(\mathrm{p}=0.08)$. There was a positive correlation between the presence of obesity and mean IOP measurements $(r=0.847, p=0.011)$, and besides a negative correlation was detected between mean RNFL thickness and mean weight of the patients $(r=-0.749, p=0.039)$.
\end{abstract}

Conclusion: In current study, it should be kept in mind that elevated IOP and decrement of RNFL thickness in children with obesity increased the risk of developing glaucoma, as well as decreased CFT and SFCT may form the basis for the development of macular diseases in future.

Keywords: Obesity, ocular parameters, children.

Çocuklarda Obezite ile Santral Retina Kalınlığı, Retina Sinir Lifi Tabakası, Göz İ̧i Basınci ve Santral Kornea Kalınlığı Arasındaki Illişkilerin Değerlendirilmesi

ÖZET

Amaaç: Bu çalışmanın amacı çocukluk çağı obezitesinin retina sinir lifi tabakası (RSLT), retina kalınlığı, santral kornea kalınlığı ve göz içi basıncı üzerine etkisini araşıırmaktır.

Hastalar ve Yöntem: Obeziteli çocuklar (n:24) (Grup 1; n:48 göz) ve sağlıklı çocuklar (n:23) (Grup 2; n:46 göz) çalışmaya dahil edildi. Ortalama RSLT kalınlığı, merkezi 1 mm çapındaki foveal kalınlık (MFK) ve subfoveal koroid kalınlığı (SFKK), fourier domain - optik koherens tomografi (FD-OKT) kullanılarak ölçüldü. Santral kornea kalınlığı (SKK) kontakt ultrasonik pakimetrisi ve göz içi basınc (GiB) Goldmann aplanasyon tonometrisi kullanılarak ölçüldü.

Bulgular: Ortalama GiB Grup 1'de anlamlı olarak daha yüksek ( $p=0.002$ ) ve grup 1'de $16.1 \pm 3.1 \mathrm{mmHg}$ ve grup 2'de $13.6 \pm 3.2 \mathrm{mmHg}$ bulundu. Ortalama RSLT, MFK ve SFKK grup 1'de grup 2'ye göre anlamlı olarak daha düşük bulundu $(\mathrm{p}<0.05)$. Ortalama RSLT grup 1 'de $107.9 \pm 10.5 \mu \mathrm{m}$ ve grup $2^{\prime} \mathrm{de} 112.6 \pm 11.8 \mu \mathrm{m}$ olarak saptandı $(\mathrm{p}=0.001)$. Ortalama MFK grup 1 'de $231.6 \pm 14.4 \mu \mathrm{m}$ ve grup $2^{\prime}$ de $245.9 \pm 19.98 \mu \mathrm{m}$ bulundu ( $p=0.001$ ). Ortalama SFKK sirasılyla grup 1'de $193.3 \pm 15.3 \mu \mathrm{m}$ ve grup $2^{\prime}$ 'de $221 \pm 25.1 \mu \mathrm{m}$ olarak gözlendi $(p<0.001)$. Grup 1'de SKK göreceli olarak daha yüksek olmasına rağmen gruplar arasında istatistiksel olarak anlamlı bir fark gözlenmedi ( $p=0.08)$. Obezite varlığı ile ortalama GiB ölçümleri arasında pozitif korelasyon $(r=0.847, p=0.011)$ ve ayrıca ortalama RSLT kalınlığı ile hastaların ortalama ağırlığı arasında negative bir korelasyon saptandı $(r=-0.749, p=0.039)$.

Sonuç: Bu çalışmada obezitesi olan çocuklarda GiB değerinin yüksekliğinin ve RSLT kalınlığııı azalmasının glokom gelişme riskini artırdığı, aynı zamanda azalmış MFK ve SFKK' nın gelecekte makula hastalıklarının gelişimine temel oluşturabileceği göz önünde bulundurulmalidir.

Anahtar kelimeler: Obezite, oküler parametreler, çocuklar. $\begin{array}{ll}\text { Received } & : 4 \text { September } 2021 \\ \text { Accepted } & : \text { 19 November } 2021\end{array}$ 
besity is an important public health problem that is increasing in both developed and developing countries. The number of overweight and obese children in the world is 43 million, of which 35 million live in developed countries. The prevalence of overweight and obesity in 2010 was $6.7 \%$, and this is predicted to rise to $9.1 \%$ by 2020 in the world (1).

Obesity causes numerous health, social and economic problems. Global expenditure for medicine has been found to be $30 \%$ higher than for individuals of normal weight (2). Hyperinsulinemia triggers various systemic disorders such as impairement of glucose tolerance, type 2 diabetes mellitus, hypertension, hyperlipidemia, sleep apnea syndrome and menstrual cycle disturbance in association with polycystic ovarian syndrome and depression are seen in majority of the patients (3-5).

Elevated intraocular pressure (IOP) is the major risk factor for glaucoma, and at the same time only treatable risk factor for disease (6). IOP measurement can be affected by various factors. The most important is central corneal thickness (CCT). A thin cornea is a significant risk factor in terms of development of glaucoma (7).

Optical coherence tomography (OCT) is a non-invasive diagnostic technique providing high-resolution, crosssectional images of the retina using near-infrared light and giving quantitative informations (8). OCT is used in diagnosis, treatment and monitoring of retinal thickness, retinal pathologies and optic nerve-related glaucoma $(9,10)$. The purpose of this study was to investigate whether or not childhood obesity affects ocular parameters.

\section{MATERIALS AND METHODS}

\section{Patients}

Children with obesity and healthy children who were under outpatient follow-up between January 2013 and January 2014 in the Pediatric Endocrinology Clinic of the tertiary university hospital were included in the study. The study was implemented in a prospective and controlled manner. Approval conforming to the Helsinki Declaration was obtained from the local ethical committee before the study commenced. Children whose parents provided informed consent were enrolled.

All ophthalmological examinations were carried out by the same ophthalmologist. Absence of any ophthalmological or systemic disease that might affect RNFL or retinal thickness was confirmed. Subjects with corneal pathology, using contact lenses, with a history of intraocular surgery or using topical eye drops were excluded.

Visual acuity measurement was performed from 4 meters on an Early Treatment Diabetic Retinopathy Study (ETDRS) chart. Best corrected visual acuity (BCVA) was converted to Snellan chart. Ophtalmic examination was performed with a slit lamp biomicroscopy following pupil dilatation with $0.5 \%$ phenylephrine hydrochloride and $0.1 \%$ tropicamide. Fundus photographs were taken after each examination. All eyes included in the study were emmetropic.

\section{Height and Weight Measurements}

All participants included in the study were weighed and measured. Measurements made by a single physician (A.C.) using the same scale.

In height measurement, a measuring stick that was sensitive to $1 \mathrm{~mm}$ and fixed to a wooden base with a mobile indicator at the top was used (Holtain, Ltd, Crymych, Dyfed, UK). Patients stood barefoot on their feet flat on the ground and heels together with the back of the head, lower back, hips and shoulders in contact with the device and their heads in an upright position and looking straight ahead. The indicator was then depressed onto the top of the head. Weight was measured using a NAN Scale TSE No:5094 system and patients stood on the device barefoot with a fixed clothing weight of $440 \mathrm{gr}$ and subsequently data were recorded. Percent optimal body weight and body mass index (BMI) (weight $(\mathrm{kg}) /$ height squared $\left(\mathrm{m}^{2}\right)$ ) were calculated for each participant from the height and weight measurements were obtained. Body weight and growth percentile charts prepared on the basis of sex and age were used in calculating percent of ideal body weight. Participants were classified by weight by comparing ideal weight values for each child with age-adjusted international cut-off values. BMI (weight in kilograms divided by the square of the height in meters) is correlated sufficiently with direct measures of fatness (4). Accordingly, a child with a BMI above the $97^{\text {th }}$ percentile in regard to age and gender is considered to be an obese group (group 1). A child with a BMI greater than the $90^{\text {th }}$ but below the $97^{\text {th }}$ percentile would be considered to be overweight and these participants excluded from the study. Participants with BMI between $5^{\text {th }}$ and $90^{\text {th }}$ percentile were enrolled at the healthy control group (group 2) (11). 


\section{Optical Coherence Tomography Measurement}

The RTVue-100 OCT (Optivue Inc., Fremont, Ca) is a Fourier-Domain (FD) A-scan instrument with an axial resolution of $5 \mu$ and a scanning speed of $26,000 / \mathrm{sec}$. Optic nerve fiber layers, retinal thickness in a $1 \mathrm{~mm}$-diameter circular region at the fovea (CFT) and subfoveal choroidal thickness (SFCT) benath the fovea were measured using the RTVue-100 device following pupillary dilation. The optic nerve head $(\mathrm{ONH})$ protocol consists of 12 radial scans of $3.4 \mathrm{~mm}$ and 6 concentric ring scans ranging between 2.5 and $4.0 \mathrm{~mm}$ in diameter, all of which are focused on the optic disc. The $\mathrm{ONH}$ protocol is employed to produce a polar RNFL thickness map. This is calculated along a $3.45-\mathrm{mm}$ diameter circle based on the optic disc. This provides a mean RNFL thickness in the temporal, superior, nasal and inferior quadrants, in addition to a total mean along the complete measurement circle. The MM5 protocol which comprises an intense $(5 \times 5) \mathrm{mm}$ network of linear scans performed around the macula. This protocol involves more rapid scans, 12 horizontal and 12 vertical, at $0.5 \mathrm{~mm}$ intervals. Each line scan consists of $512 \mathrm{~A}$-scans over a $5 \mathrm{~mm}$ scanning length.

Mean retinal thickness in a $1 \mathrm{~mm}$-diameter circle at the fovea (CFT) was calculated by means of EMM5 software for the RTVue-100.

Subfoveal choroidal thickness (SFCT) measurements were provided by the EDI-OCT imaging method defined by Spaide (12). SFCT was characterized as the vertical distance from the basal edge of retinal pigment epithelium below the central fovea to the endpoint of the choroidscleral junction. Figure 1 shows macular measurements of an obese patient. Figure 2 shows optic nerve head measurements from an healthy individual.

\section{Intra-ocular Pressure and Central Corneal Thickness Measurement}

Intra-ocular pressure was measured under topical anesthesia (proparacaine $\mathrm{HCl} 0.5 \%$ ) using with Goldmann applanation tonometry (GAT, Haag Streit, Koeniz, Switzerland). CCT was measured using contact ultrasonic pachymetry (Pacline Opticon 2000 spa, Rome, Italy) at least 3 times for each eye and the lowest CCT value was selected for statistical analysis.

\section{Statistical Analysis}

Descriptive statistics (mean, standard deviation, minimum and maximum values) were used in the study and the paired sample $t$ test was used to compare numerical data between the groups. Shapiro Wilk test was used to check whether the distribution between the groups was homogeneous. Generalized equation estimation (GEE) analysis was used for statistical analysis, since the double eyes were included in the study in some patients. Statistical significance was defined as $p<0.05$. Pearson correlation test was used to determine the linear relationship between variables. SPSS 20.0 package version was used for statistical analysis.

\section{RESULTS}

A total of 94 eyes of 47 participants were included in the study that 48 eyes of 24 children were in the obese group (group 1) and 46 eyes of 23 children were in the healthy individual group (group 2), respectively. Descriptive characteristics (age, weight, height, gender distribution) of each groups are shown in Table 1.

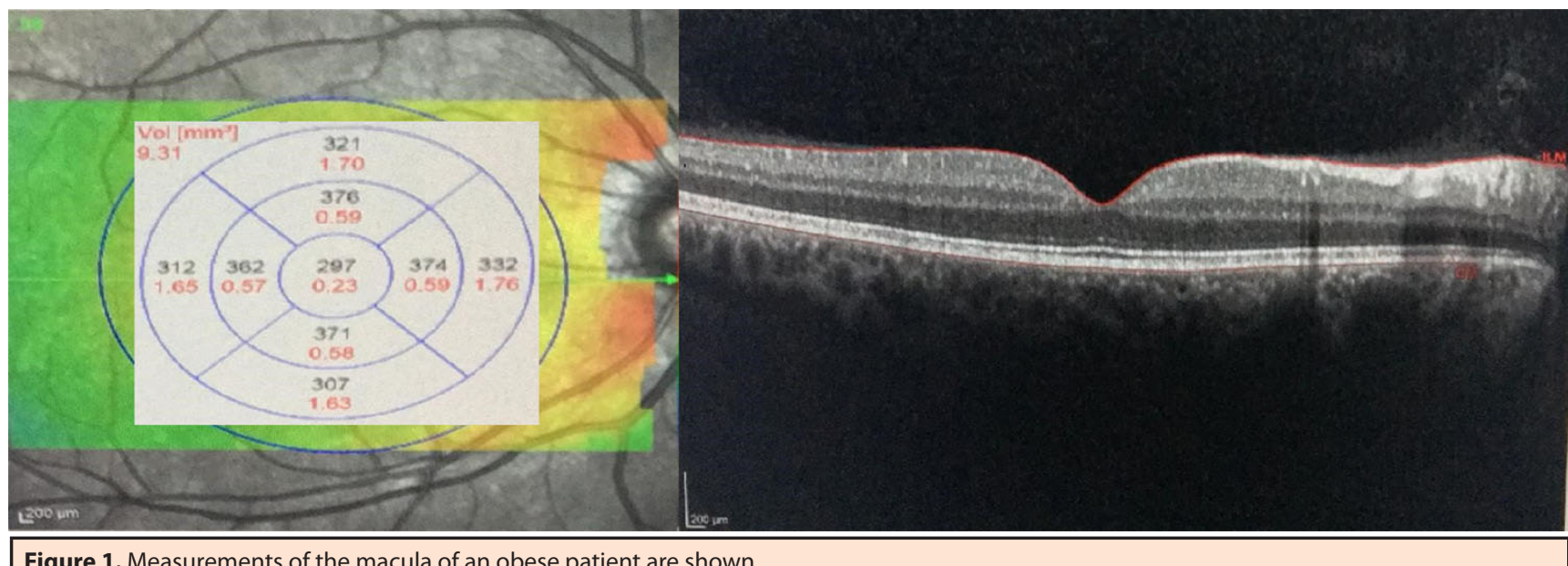

Figure 1. Measurements of the macula of an obese patient are shown. 

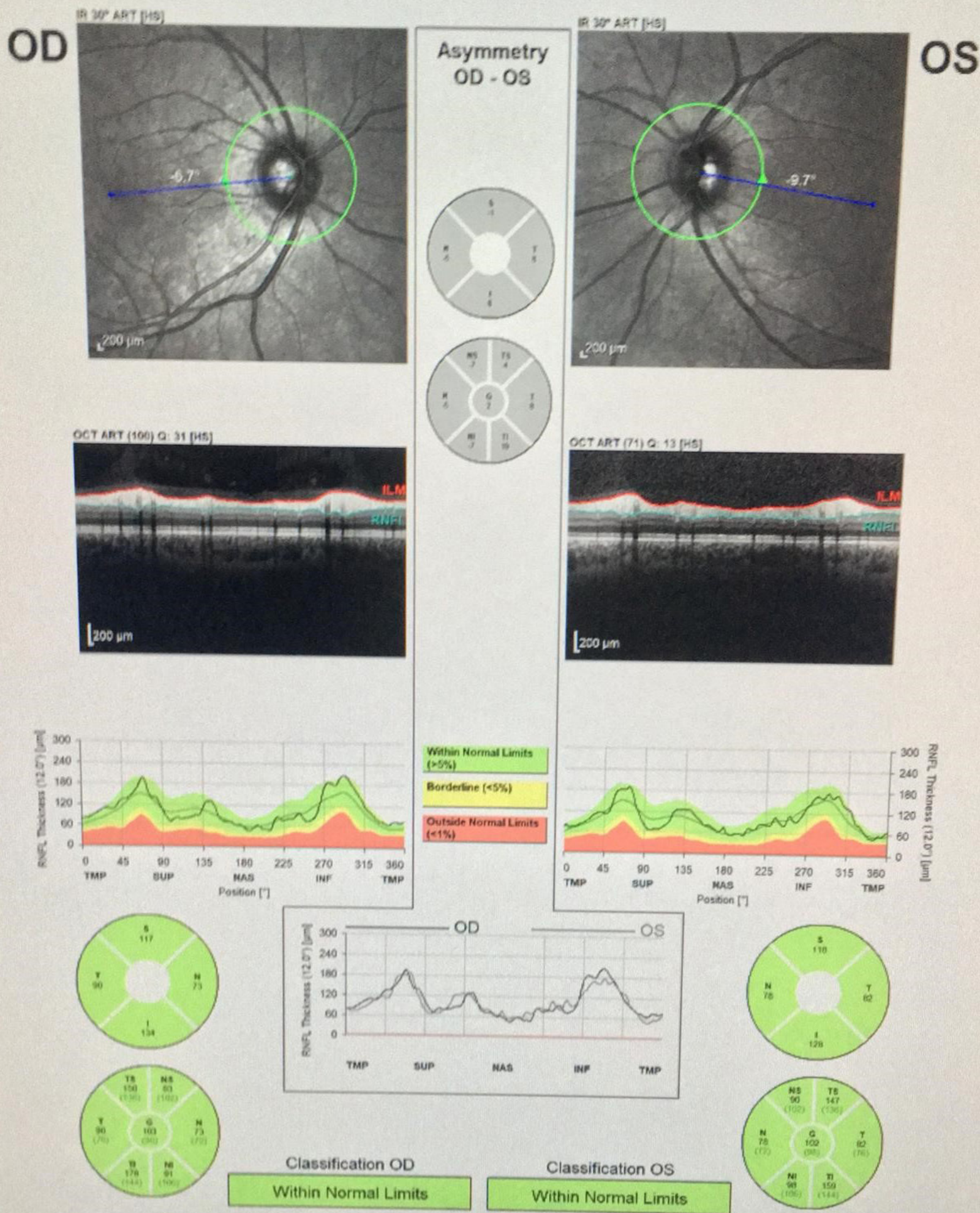

$O D$
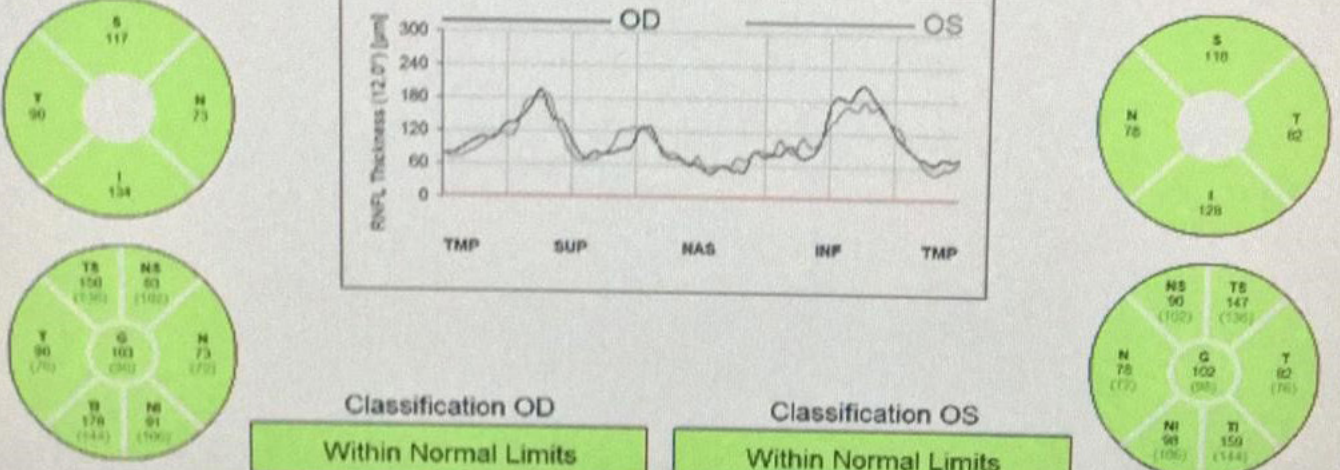

MAS
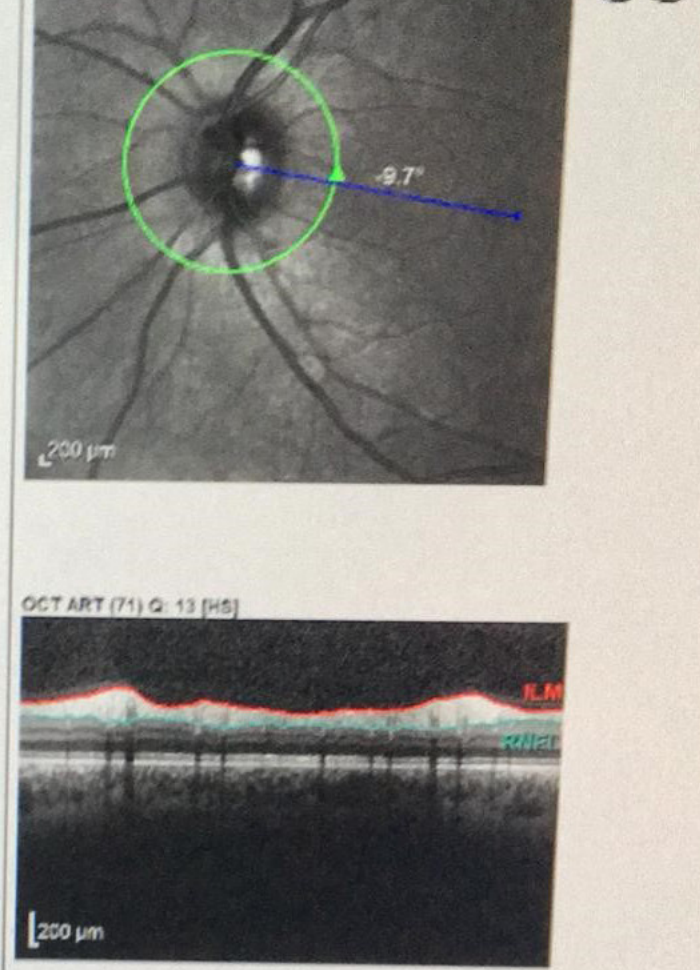

os 
Table 1: Demographic characteristics of groups

\begin{tabular}{|c|c|c|c|}
\hline Mean \pm SD & $\begin{array}{c}\text { Group 1 } \\
\text { Obese group } \\
(\mathbf{n = 4 8 )}\end{array}$ & $\begin{array}{c}\text { Group 2 } \\
\text { Control Group } \\
(\mathbf{n}=\mathbf{4 6})\end{array}$ & $\boldsymbol{p}$ values \\
\hline Age (years) & $11.4 \pm 1.8$ & $11.8 \pm 1.6$ & $\boldsymbol{p}=\mathbf{0 . 8 9 7}$ \\
\hline Weight (kg) & $58 \pm 15.9$ & $37.8 \pm 8.3$ & $\boldsymbol{p}<\mathbf{0 . 0 0 1}$ \\
\hline Height (cm) & $147.5 \pm 14.3$ & $146.6 \pm 10.6$ & $\boldsymbol{p}=\mathbf{0 . 7 9 2}$ \\
\hline $\begin{array}{c}\text { Male/Female } \\
\text { (n) }\end{array}$ & $23 / 25$ & $24 / 22$ & $\boldsymbol{p}=\mathbf{0 . 7 4 9}$ \\
\hline $\begin{array}{l}\text { Student } t \text { test } \\
\text { n:number; } S D \text {, standard deviation. }\end{array}$ & & \\
\hline
\end{tabular}

No statistically significant difference was determined among the groups in terms of mean age and height, and gender distributions ( $p>0.05)$. Mean weight were significantly higher in Group $1(p<0.001)$.

The mean IOP in Group 1 was found to be significantly higher $(p=0.002)$ and $16.1 \pm 3.1 \mathrm{mmHg}$ in group 1 and 13.6 $\pm 3.2 \mathrm{mmHg}$ in group 2, respectively. Mean RNFL, CFT and SFCT significantly were lower in group $1(p<0.05)$ than group 2 . The average RNFL was detected to $107.9 \pm 10.5$ $\mu \mathrm{m}$ in group 1 and $112.6 \pm 11.8 \mu \mathrm{m}$ in group 2, respectively $(p=0.001)$. Mean CFT was found to be $231.6 \pm 14.4 \mu \mathrm{m}$ in group 1 and $245.9 \pm 19.98 \mu \mathrm{m}$ in group 2 , respectively $(p=0.001)$. The average SFCT was observed to $193.3 \pm 15.3$ $\mu \mathrm{m}$ in group 1 and $221 \pm 25.1 \mu \mathrm{m}$ in group 2 , respectively $(p<0.001)$. Although CCT was relatively higher in group 1 , no statistically difference was observed among the groups $(p=0.08)$.

There was a positive correlation between the presence of obesity and mean IOP measurements $(r=0.847, p=$ 0.011 ), and besides a negative correlation was detected between mean RNFL thickness and mean weight of the patients $(r=-0.749, p=0.039)$.

The results of the study are summarized in Table 2 . The graphic of outcomes in study is given in Figure 3.

\begin{tabular}{|c|c|c|c|}
\hline Mean \pm SD & $\begin{array}{c}\text { Group } 1 \\
\text { Obese Group } \\
(n=48)\end{array}$ & $\begin{array}{c}\text { Group 2 } \\
\text { Control Group } \\
(n=46)\end{array}$ & $p$ values \\
\hline CFT, $\mu \mathrm{m}$ & $231.6 \pm 14.4$ & $245.9 \pm 19.9$ & $p=0.001^{*}$ \\
\hline $\mathrm{SFCT}, \mu \mathrm{m}$ & $193.3 \pm 15.3$ & $221 \pm 25.1$ & $p<0.001^{*}$ \\
\hline Mean RNFL, $\mu \mathrm{m}$ & $107.9 \pm 10.5$ & $112.6 \pm 11.8$ & $p=0.019 *$ \\
\hline IOP, mmHg & $16.1 \pm 3.1$ & $13.6 \pm 3.2$ & $p=0.002^{*}$ \\
\hline $\mathrm{CCT}, \mu \mathrm{m}$ & $578.9 \pm 41.6$ & $573 \pm 34.5$ & $p=0.08$ \\
\hline \multicolumn{4}{|c|}{$\begin{array}{l}\text { Student t test } \\
\text { CFT: Central } 1 \text { mm foveal thickness, } \\
\text { SFCT: Subfoveal choroidal thickness at the foveal pit, } \\
\text { RNFL: Retinal nerve fiber layer, } \\
\text { IOP: Intraocular pressure, CCT: Central corneal thickness. } \\
\text { n:number; SD, standard deviation. }\end{array}$} \\
\hline
\end{tabular}

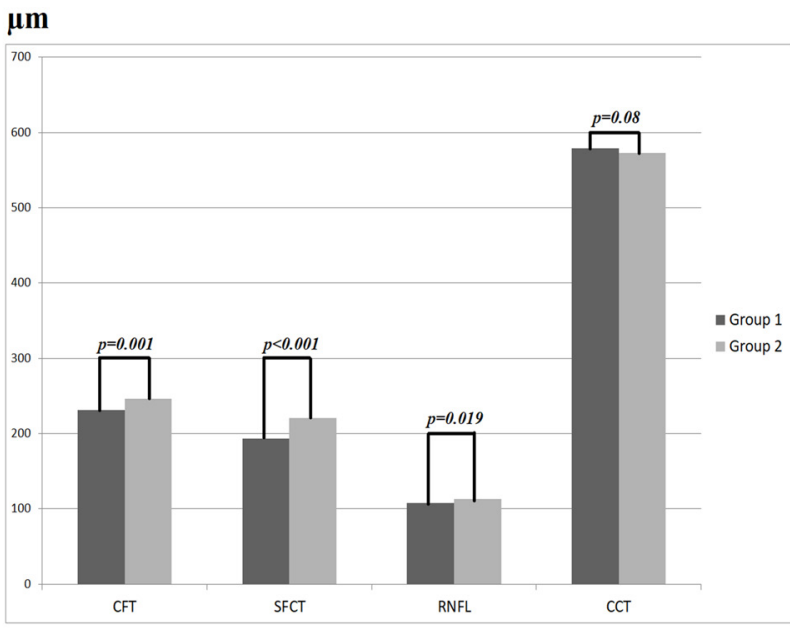

Figure 3. The graphic of the results is summarized in the study.

\section{DISCUSSION}

In this study, it was aimed to investigate whether childhood obesity affects ocular parameters. A significant decrease in SFCT, CFT, RNFL and a significant increase in IOP were observed in obese children. High IOP values often lead to glaucomatous optic nerve damage and visual field loss (6). Studies on adults have been reported conflicting views on IOP and obesity. Some studies have reported a positive correlation between IOP and obesity $(13,14)$ while another one has determined no significant correlation. Those studies identifying a positive correlation between IOP and obesity have proposed two different views; an elevation in IOP associated with increased blood viscosity and pressure in the episcleral veins related to increased fatty tissue in the orbita due to obesity, or a rise in IOP as a result of autonomous dysfunction disorders associated with insulin resistance in obese children (14). Akıncı et al (15) pointed out that there was a positive correlation between obesity and IOP while Albuquerque et al. (16) reported that they were not found any correlation between obesity and IOP measurements. Although present study was implemented in Turkish cohorts, our results were consistent with a study by Akıncı et al (15). Measurement of IOP is important for early diagnosis, treatment and monitoring of glaucoma. The accuracy of IOP measurements is critical for before and after glaucoma therapy and CCT is one of the parameters that most affect IOP values. Studies have shown that the thinner the cornea, the lower the IOP were found and also the thicker the cornea, the higher the IOP were observed (17-19). 
Some studies have examined the association between obesity and CCT, and as far as we know, all of these involved in adults. The Singapore Malay Eye Study (SiMES) measured CCT using ultrasonic pachymetry and investigated whether or not systemic factors were affected CCT. Significantly high IOP was determined in subjects with high BMls (20). The Gutenberg Health Study pointed out that there was a positive correlation among CCT and BMI (21). A study from Japan involving specular microscopy also determined significantly high CCT in obese adults (22). In a study of Teberik et al., intraocular pressure measurements were found to be significantly higher in the morbidly obese group compared to the healthy control group which were consisted of adult participants (15.5 \pm 2.5 vs. $14.5 \pm 2.6 \mathrm{mmHg}, \mathrm{p}=0.009$ ). However, CCT did not differ between healthy and the morbid obese participants ( $p>0.05$ ). The number of participants consisted of 101 morbid obese volunteers (body mass index $[\mathrm{BMI}] \geq 40$ ) and 95 healthy individuals (BMI: 18.50-24.99) (23). In our study, CCT values measured by ultrasound pachymetry tended to increase in obese children and significantly difference was found compared to the control group in Turkish cohort for children obesity.

Optical coherence tomography as a noninvasive technique which has been frequently preferred recent years in terms of evaluating macular thickness and RNFL in patients with glaucoma has been used by physicians $(24,25)$. Obese children were measured in our study and a significant differences were found to be in retinal parameters. Mean CFT and SFCT values were lower than control healthy children $(p<0.05)$.

Glaucoma is an optical neuropathy characterized by progressive loss of visual field accompanied by degeneration in retinal ganglion cells and RNFL. The relation between $\mathrm{BMI}$ and cup-to-disc ratio is controversial in studies involving adults. Wider neuroretinal thickness and, a small optic nerve and cup-to-disc ratio have been determined in subjects with high BMI. It has been suggested that high BMI leads to increased cerebrospinal fluid pressure and thus an increment of neuroretinal rim area in patients with high BMI $(26,27)$. However, other studies have been reported no association between BMI and cup-to-disc ratio $(28,29)$. In a study conducted by Baran et al. has been reported alterations in ophthalmological parameters including IOP, RNFL, GCL, CMT, SFCT and cup-to-disc ratio in 61 obese children compared to 35 matched control children. IOP levels was higher in obese group than control healthy group $(p=0.008)$, whereas mean RNFL was significantly lower in obese group $(p=0.035)$. Also they found that there was a negative correlation among the mean RNFL and BMI ( $p=-0.044)$. There was no significant difference between the two groups in terms of RGC, C / D, CMT, and SFCT results $(p>0.05)$. They suggested that high IOP and reduction of RNFL thickness may increase the risk of developing glaucoma at a younger age in obese children (30). In a study implemented by Demir et al., they aimed to compare the RNFL, thickness of the ganglion and inner plexiform layer analysis of peripapillary optic nerve head (PONH) and macula of two independent groups which were 85 obese children and 30 healthy children, respectively. RNFL thickness of temporal outer macula for obesity and control groups was $261.7 \pm 13.7$ and $268.9 \pm 14.3 \mu \mathrm{m}$, respectively $(p=0.034)$. Apart from this, there was no significant difference between the two groups in other parameters ( $p>0.05)(31)$.

The advantages of our study includes child age group and detailed parameters compared to above studies. Its disadvantages are its retrospective design and small sample size.

To the best of our knowledge, only one study has considered the association between obesity and RNLF in children. In an investigation of RNLF with a mean age of 12 in China, Zhu et al (32) reported a mean RNLF of $103.08 \mu \mathrm{m}$, and determined no significant correlation between $\mathrm{BMI}$ and RNLF. Mean RNLF in our study was $108.9 \mu \mathrm{n}$ in children of normal weight and $112.6 \mu \mathrm{m}$ in obese children. RNLF had a tendency to elevation in obese children, although no statistically significant difference was determined compared to the control group. Our RNLF values being higher than those determined by Zhu et al. (32) may be attributed to variation in RNLF values between ethnic groups.

In conclusion, obesity in childhood has a significant effect on IOP, central retinal or RNLF values in Turkish cohort. Although CCT values were relatively higher in the obese group, no significant difference was observed compared to the healthy subjects. In current study, it should be kept in mind that elevated IOP and decrement of RNFL thickness on optic nerve head in children with obesity increased the risk of developing glaucoma, as well as decreased CFT and SFCT may form the basis for the development of macular diseases in future life. Future studies should assess whether there is any change with age and accompanying diseases in ocular parameters in obese children under long-term monitoring. 


\section{DECLARATIONS}

Funding: This research received no specific grant from any funding agency in the public, commercial, or notfor-profit sectors.

Conflict of Interest: No conflicting relationship exists for any author.

Ethical Approval: All procedures performed in studies involving human participants were in accordance with the ethical standards of the institutional and/or national research committee and with the 1964 Helsinki declaration and its later amendments or comparable ethical standards.

Informed Consent: Informed consent was obtained prior to every surgical procedure from all individual participants included in the study.

\section{REFERENCES}

1. De Onis M, Blössner M, Borghi E. Global prevalence and trends of overweight and obesity among preschool children. Am J Clin Nutr. 2010;92:1257-64.

2. Withrow $D$, Alter DA. The economic burden of obesity worldwide: A systematic review of the direct costs of obesity. Obes Rev. 2011;12:131-41.

3. Freedman DS, Mei Z, Srinivasan SR, et al. Cardiovascular risk factors and excess adiposity among overweight children and adolescents: The Bogalusa heart study. J Pediatr. 2007;150:12-7.

4. Whitlock EP, Williams, SB, Gold R, et al. Screening and interventions for childhood overweight: A summary of evidence for the US Preventive Services Task Force. Pediatrics 2005;116:125-44.

5. Ickes MJ, Mullen JM, Manoj TH. Sharma Global School-Based Childhood Obesity Interventions: A Review Int. J. Environ. Res. Public Health 2014;11:8940-61.

6. Mumcuoğlu T, Durukan $\mathrm{H}$, Hürmeriç V, et al. Relationship Between Introcular Pressure, Central Corneal Thickness and Visual Field Defects in Glaucoma and Ocular Hypertension. Journal of Glaucoma - Cataract 2006, Vol 1, Num 2.

7. Arıtürk N. Central Corneal Thickness Measurement and its Importance in Glaucoma. Journal of Glaucoma - Cataract 2006, Vol 1, Num 1.

8. Tuncer İ, Karahan E, Zengin MÖ, et al. Comparison of Scheimpflug Imaging and Optical Coherence Tomography in the Measurement of Central Corneal Thickness. Journal of Glaucoma - Cataract 2014, Vol 9, Num 1.

9. Leung CK, Liu S, Weinreb RN, et al. Evaluation of retinal nerve fiber layer progression in glaucoma a prospective analysis with neuroretinal rim and visual field progression. Ophthalmology. 2011;118:1551-57.

10. Bardak H, Bardak Y. Comparison of Central Corneal Thickness Measurement By Different Methods in Glaucoma Patients. Journal of Glaucoma - Cataract 2015, Vol 10, Num 3.

11. Farpour-Lambert NJ, Baker JL, Hassapidou M, et al. Childhood Obesity Is a Chronic Disease Demanding Specific Health Care--a Position Statement from the Childhood Obesity Task Force (COTF) of the European Association for the Study of Obesity (EASO). Obes Facts 2015;8(5):342-9.

12. Spaide RF, Koizumi H, Pozzoni MC. Enhanced depth imaging spectral-domain optical coherence tomography. Am J Ophthalmol. 2008 Oct;146(4):496-500.
13. Mori $\mathrm{K}$, Ando $\mathrm{F}$, Nomura $\mathrm{H}$, et al. Relationship between intraocular pressure and obesity in Japan. Int J Epidemiol. 2000;29:661-66.

14. Cheung N, Wong TY. Obesity and eye diseases. Surv Ophthalmol. 2007; $52: 180-95$

15. Akinci A, Cetinkaya E, Aycan Z, et al. Relationship between intraocular pressure and obesity in children. J Glaucoma. 2007;16:627-30.

16. Albuquerque LL, Gaete MI, Figueiroa JN, et al. The correlation between body mass index and intraocular pressure in children. Arq Bras Oftalmol. 2013;76:10-12.

17. Gasser $P$, Stümpfig $D$, Schötzau A, et al. Body mass index in glaucoma. J Glaucoma. 1999;8:8-11.

18. Park SS, Lee EH, Jargal G, et al. The distribution of intraocular pressure and its association with metabolic syndrome in a community. J Prev Med Public Health. 2010;43:125-30.

19. Hoffmann EM, Lamparter J, Mirshahi A, et al. Distribution of central corneal thickness and its association with ocular parameters in a large central European cohort: the Gutenberg health study. PLoS One. 2013;8:66158.

20. Su DH, Wong TY, Foster PJ, et al. Central corneal thickness and its associations with ocular and systemic factors: the Singapore Malay Eye Study. Am J Ophthalmol. 2009;147:709-16.

21. Elflein HM, Pfeiffer N, Hoffmann EM, et al. Correlations between central corneal thickness and general anthropometric characteristics and cardiovascular parameters in a large European cohort from the Gutenberg Health Study.Cornea. 2014;33:359-65.

22. Nishitsuka $K$, Kawasaki R, Kanno M, et al. Determinants and risk factors for central corneal thickness in Japanese persons: the Funagata Study. Ophthalmic Epidemiol. 2011;18:244-49.

23. Teberik K, Eski MT, Doğan S, et al.Ocular abnormalities in morbid obesity. Arq Bras Oftalmol. 2019 Jan-Feb;82(1):6-11.

24. Badaró E, Novais E, Prodocimo LM, et al. Spectral-domain optical coherence tomography for macular edema. Scientific World Journal. 2014;2014:191847.

25. Sakata LM, Deleon-Ortega J, Sakata V, et al. Optical coherence tomography of the retina and optic nerve - a review. Clin Experiment Ophthalmol. 2009;37:90-9.

26. Wong AC, Chan CW, Hui SP. Relationship of gender, body mass index, and axial length with central retinal thickness using optical coherence tomography. Eye (Lond). 2005;19:292-97.

27. Hirooka K, Manabe S, Tenkumo K, et al. Use of the structure-function relationship in detecting glaucoma progression in early glaucoma. BMC Ophthalmol. 2014;14:118.

28. Zheng Y, Cheung CY, Wong TY, et al. Influence of height, weight, and body mass index on optic disc parameters. Invest Ophthalmol Vis Sci. 2010;51:2998-3002.

29. Jonas JB, Nangia V, Gupta R, et al. Retinal nerve fibre layer crosssectional area, neuroretinal rim area and body mass index. Acta Ophthalmol. 2014;92:194-99.

30. R T Baran , S O Baran , N F Toraman, et al. Evaluation of intraocular pressure and retinal nerve fiber layer, retinal ganglion cell, central macular thickness, and choroidal thickness using optical coherence tomography in obese children and healthy controls. Niger J Clin Pract. 2019 Apr;22(4):539-545.

31. Demir S, Özer S, Alim S, et al. Retinal nerve fiber layer and ganglioninner plexiform layer thickness in chidren with obesity. Int J Ophthalmol. 2016 Mar 18;9(3):434-8.

32. Zhu BD, Li SM, Li H, et al. Retinal nerve fiber layer thickness in a population of 12-year-old children in central China measured by iVue-100 spectral-domain optical coherence tomography: the Anyang Childhood Eye Study. Invest Ophthalmol Vis Sci. 2013:54:8104-11. 